\title{
PENINGKATAN SIKAP SERTA HASIL BELAJAR PESERTA DIDIK SMANEGERI 9 MALANG MELALUI METODE PROJECT BASED LEARNING (PJBL)
}

\author{
Andy Laksono PrasetyoWibowo \\ Jurusan Biologi Fakultas Matematika dan Ilmu Pengetahuan Alam \\ Universitas Negeri Malang
}

\begin{abstract}
ABSTRAK
Penelitian ini bertujuan untukmengetahui pengaruh penerapan metode Project Based Learning terhadap sikap peserta didik kelas X SMA Negeri 9 Malang, dan mengetahui pengaruh penerapan metode Project Based Learning terhadap hasil belajar peserta didik kelas X SMA Negeri 9 Malang. Sampel yang digunakan adalah peserta didik kelas X 2 dan X 3 SMA Negeri 9 Malang. Instrumen penelitian yang digunakan adalah: silabus, RPP, buku ajar peserta didik, Lembar Kerja Peserta Didik, Identification Sheet, panduan evaluasi produk peserta didik, dan perangkat tes. Data penelitian ini merupakan data kuantitatif yang terdiri dari skor sikap terhadap ekosistem sungai dan kognitif peserta didik. Data dianalisis dengan analisis statistik kovarian (ANAKOVA) serta dilanjutkan dengan uji beda LSD. Peserta didik yang difasilitasi pembelajaran berbasis proyek memiliki sikap dan pemahaman konsep lebih tinggi $6,2 \%$ dan $47,31 \%$ dari peserta didik yang difasilitasi pembelajaran konvensional.
\end{abstract}

Kata kunci: metode PjBL, pemahaman konsep, sikap terhadap ekosistem sungai

\section{PENDAHULUAN}

Perkembangan

pendidikan nasional dapat dilihat dari perkembangan kurikulum nasional, karena kurikulum merupakan penentu aliran pendidikan ke arah yang lebih sempit (sekolah tingkat atas, menengah maupun dasar). KTSP merupakan paradigma baru pengembangan kurikulum yang memberikan otonomi luas pada setiap satuan pendidikan. Otonomi diberikan agar setiap satuan pendidikan dan sekolah memiliki keleluasaaan dalam mengelola sumber daya, sumber dana, sumber belajar, dan mengalokasikannya sesuai prioritas kebutuhan, serta lebih tanggap terhadap kebutuhan setempat (Mulyasa, 2006).

Mata pelajaran Biologi memungkinkan untuk menghubungkan antara teori dengan praktek yang bersifat membangun pengetahuan peserta didik (konstruktivistik) terhadap lingkungan sekitar, sehingga tujuan KTSP dimungkinkan dapat tercapai secara maksimal. Menurut Permendiknas RI no 22 tahun 2006 matapelajaran Biologi dikembangkan melalui kemampuan berpikir analitis, induktif, dan deduktif untuk menyelesaikan masalah yang berkaitan dengan peristiwa alam sekitar. Peristiwa alam sekitar yang mudah diamati dan sering berdekatan dengan aktifitas peserta didik adalah lingkungan perairan sungai Brantas.

Perairan sungai Brantas cukup dekat dengan aktivitas penduduk sekitar, karena sungai Brantas sering dimanfaatkan penduduk untuk bermacammacam kegiatan, antara lain: mandi, mencuci, mengairi sawah, tempat pembuangan limbah rumah tangga dan industri yang berupa padatan maupun cairan. Pemanfaatan sungai Brantas yang tinggi tanpa memperdulikan kondisi sungai Brantas dapat mengakibatkan penurunan kualitas perairan maupun ekologis sungai Brantas.

Penelitian yang dilakukan oleh Wibowo (2007) menunjukkan bahwa berdasar evaluasi terpadu antara parameter Fisiko-kimia dan indikator Biologi menunjukkan bahwa kualitas air sungai Brantas Kota Malang bagian hulu belum tercemar, sedangkan bagian lainnya tercemar ringan. Kondisi ini 
cukup memprihatinkan mengingat kebutuhan air bersih semakin bertambah seiring dengan meningkatnya jumlah penduduk yang akan menggunakan air untuk keperluan rumah tangga, pertanian, perindustrian, dan perikanan.

Pemulihan kondisi sungai melalui self purification membutuhkan waktu yang cukup lama, kemampuan setiap sungai dalam melakukan regulasi juga mempunyai keterbatasan. Salah satu cara untuk mengembalikan kondisi sungai adalah dengan memberikan pendidikan sebagai pencegahan pencemaran yang menekankan pada pemahaman konsep (kognitif) dan sikap peserta didik terhadap ekosistem sungai. Peserta didik diharapkan benar-benar memahami fungsi sungai dan akibat yang ditimbulkan pencemaran terhadap semua faktor biotikabiotik yang terkait dengan sungai tersebut.

Menurut Aiken (1970) dalam Mahanal (2009) sikap adalah kecenderungan yang dipelajari seorang individu untuk merespon secara positif atau negatif dengan intensitas yang moderat atau memadai terhadap obyek, situasi, konsep, atau orang lain. Hal ini berarti sikap merupakan hasil belajar. Oleh karena itu, sikap dapat diubah dan dikembangkan melalui pendidikan dengan menggunakan prinsip-prinsip belajar tertentu. Selanjutnya dikemukakan oleh Middlebrook dalam Azwar (2007) bahwa tidak adanya pengalaman sama sekali dengan obyek psykologis cenderung akan membentuk sikap negatif terhadap obyek tersebut.

Sains tidak hanya sebagai dasar untuk mengembangkan teknologi tetapi juga dasar pengembangan nilai dan sikap. Sikap dibentuk berdasarkan nilai dan pemahaman seseorang terhadap sains. Dengan demikian perlu upaya meningkatkan pemahaman peserta didik terhadap konsep-konsep sain yang berdampak pada pengembangan sikap (Dreyfus, 1995).
Alternatif yang dapat digunakan untuk mengembangkan hasil belajar peserta didik yang nantinya juga berpengaruh terhadap sikap peserta didik terhadap lingkungan adalah melalui model pembelajaran yang berbasis konstruktivis. Melalui pembelajaran konstruktivis pengetahuan akan dibangun sendiri oleh peserta didik secara aktif melalui perkembangan proses mental dan modal intelektualitas peserta didik, karena setiap peserta didik sudah memiliki kemampuan dasar sehingga mereka hanya membutuhkan wadah untuk mengaktualisasikan diri serta mengembangkan pengetahuan mereka tersebut.

Pengetahuan peserta didik terhadap perairan sungai mulai dibina melalui wadah JKPKA (Jaring-jaring Komunikasi Pemantau Kualitas Air) yang dibentuk oleh Perum Jasa Tirta (PJT). Salah satu SMA Negeri di Malang yang tergabung dalam JKPKA adalah SMA Negeri 9 Malang. SMA Negeri 9 bersama Perum Jasa tirta secara periodik melakukan pemantauan kualitas sungai Brantas. Pemantauan kualitas air Brantas berkaitan erat dengan pembelajaran Biologi khususnya materi ekosistem. Pembelajaran Biologi seyogyanya lebih dari sekedar menerima informasi, mengingat dan menghafal. Pembelajaran Biologi menurut Permen Diknas no 22 tahun 2006 haruslah membuat anak didik memiliki kemampuan berfikir analitis, induktif dan deduktif dengan menggunakan konsep dan prinsip Biologi, serta meningkatkan kesadaran dan berperan serta dalam menjaga kelestarian lingkungan.

Pembelajaran yang berkualitas seperti dijelaskan di atas dimungkinkan diwujudkan melalui model Project Based Learning (PjBL), karena model pembelajarannya berfokus pada konsepkonsep dan prinsip-prinsip utama dari suatu disiplin, melibatkan peserta didik dalam kegiatan pemecahan masalah dan tugas-tugas bermakna lainya, memberi 
peluang peserta didik bekerja secara otonom serta mengkonstruk belajar mereka sendiri, dan nantinya menghasilkan produk karya peserta didik bernilai, dan realistik. PjBL secara teori efektif melatih kemampuan berpikir kritis peserta didik, melatih bekerjasama dengan orang lain serta bersifat kontekstual. Mahanal (2008) PjBL mendorong peserta didik untuk berfikir analisis dan memasukkan teknologi mutakhir dalam penugasan. $\mathrm{PjBL}$ juga mendorong peserta didik untuk melakukan inkuiri dalam memahami lingkungan sekitar dan mengkonstruk pemahaman berdasarkan pengalamannya.

Alasan lain yang mendukung penggunaan $\mathrm{PjBL}$ adalah waktu pembelajaran menggunakan metode ini pada SMA Negeri 9 Malang kurang lebih 3 bulan, karena strategi PjBL membutuhkan waktu yang lama. Jangka waktu yang lama ini bertujuan untuk meningkatkan pemahan peserta didik yang selanjutnya berdampak pada sikap peserta didik SMA Negeri 9 Malang terhadap lingkungan hidup. Sikap yang dibentuk diharapkan bertahan dalam jangka waktu yang lama.

Berdasarkan uraian diatas, maka dilakukan penelitian dengan judul 'Peningkatan Sikap serta Hasil Belajar Peserta Didik SMA Negeri 9 Malang melalui Metode Project Based Learning(PjBL)'.

\section{METODE PENELITIAN}

Jenis penelitian yang diterapkan dalam penelitian ini adalah eksperimen. Rancangan penelitian yang dipilih adalah rancangan penelitian eksperimen semu (quasi). Populasi penelitian ini adalah peserta didikKelas X SMA Negeri 9 Malang semester Genap tahun pelajaran 2008-2009. Sampel penelitian ini adalah peserta didikKelas X SMA Negeri 9 Malang semester Genap tahun pelajaran 2008-2009 yang berjumlah 77peserta didik, terdiri dari kelas X2(38 peserta didik) yang digunakan sebagai kelas eksperimendan kelas X3 (39 peserta didik) yang digunakan sebagai kelas kontrol. Data penelitian ini berupa data kuantitatif yaitu skor tes pemahaman konsep dan skor sikap terhadap ekosistem sungai.Data penelitian ini dikumpulkan pada semester genap tahun ajaran 2008/2009 pada tanggal 14 Maret 200931 Mei 2009.

\section{HASIL DAN PEMBAHASAN}

Data yang digunakan dalam penelitian ini ada dua macam,antara lain: 1) data hasil belajar (penguasaan konsep); dan 2) data sikap terhadap ekosistem. Hasil belajar (penguasaan konsep) dalam penelitian ini diukur melalui tes tulis (pre tes dan pos tes), penilaian tes hasil belajar mengacu padarubrik hasil belajar (inti penilaian berupa kebenaran konsep, kemampuan analisis, dan gramatika bahasa).Data skala sikap terhadap ekosistem sungai diukur melalui angket skala sikap (pre tes dan pos tes), penilaian skala sikap terhadap ekosistem sungai mengacu pada rubrik skala sikap (inti penilaian berupa argumen sikap positif atau negatif beserta tingkatannya).

\subsection{Penguasaan konsep}

Peningkatan rerata terkoreksi peserta didik yang difasilitasi pembelajaran berbasis proyek memiliki pemahaman konsep lebih tinggi $47,31 \%$ dari peserta didik yang difasilitasi pembelajaran konvensional. Melalui uji statistik (ANAKOVA), variabel strategi pembelajaran diperoleh nilai $F_{\text {hitung }}$ sebesar 97.95 dengan nilai signifikansi 0,000 (kurang dari 0,05); dengan demikian hipotesis nol ditolak dan hipotesis penelitian diterima yang berarti ada pengaruh strategi pembelajaran terhadap penguasaan konsep.

Metode belajar PjBLmenunjukkan bahwa pemaham konsep kel as eksperimen mengalami peningkatan yang signifikan, jika dibandingkan dengan kelas kotrol yang menggunakan metode belajar konvensional (biasa dipakai Guru). 
PjBL memberikan kemampuan kognitif yang menghasilkan peningkatan pembelajaran dan kemampuan untuk lebih baik mempertahankan / menerapkan pengetahuan (Huda, 2009).

Metode belajar PjBL melibatkan berbagai tahapan yang mampu meningkatkan kognitif peserta didik, melalui proyek peserta didikmampu melibatkan seluruh mental dan fisik, syaraf, indera termasuk kecakapan sosial dengan melakukan banyak hal sekaligus. Ini adalah exercise bagi otak untuk menunjukkan kapasitas yang sesungguhnya dan tantangan ini akan mengembangkan otak kanan maupun kiri dengan pesat (Purworini, 2009).

Keunggulan PjBLselain menurut deskripsi di atas juga dijelaskan oleh Purworini (2009) yang menyatakan bahwa PjBLmeningkatkan hasil belajar peserta didik dikarenakan metode PjBLmenganut paham konstruktivis dan kontekstual, sehingga informasi yang di dapat peserta didik tidak lagi bersifat abstrak tetapi nyata dan secara umum peserta didik mendapat pengalaman langsung, menumbuhkan kemandirian, meningkatkan kerjasama diantara peserta didik meningkatkan motivasi belajar, meningkatkan hasil belajar serta mengembangkan kecakapan hidup (life skills).

Melalui proyek yang mereka kerjakan, peserta didikakan memperoleh pengetahuan yang lebih dalam, belajar mandiri serta dapat meningkatkan kemampuan dalam mengasah keterampilan memecahkan masalah (problem-solving skills) (Sasti, 2008). Kemampuan peserta didik dalam menjawab pertanyaan tertulis yang menggambarkan pemahaman konsep didapat dari kebiasaan peserta didik dalam menggali content (materi) dengan menggunakan berbagai cara yang bermakna bagi dirinya, dan melakukan eksperimen secara kolaboratif. Project Based Learning merupakan pendekatan pembelajaran yang memperhatikan pemahaman. Peserta didik melakukan eksplorasi, penilaian, interpretasi dan mensintesis informasi melalui cara yang bermakna. (The George Lucas Educational Foundation, 2005 dalam Nurohman, 2008).

Pembelajaran Berbasis Proyek dapat mengembangkan kemampuan berpikir produktif, melalui belajar kolaboratif peserta didik saling belajar yang nantinya akan meningkatkan pemahaman konseptual maupun kecakapan teknikal, holistik dan interdisipliner, realistik, berorientasi pada belajar aktif memecahkan masalah riil, yang memberi kontribusi pada pengembangan kecakapan pemecahan masalah; dan (6) memberikan reinforcement intrinsik (umpan balik internal) yang dapat menajamkan kecakapan berpikir produktif.

BIE (1999) dalam Asiska (2008) menyatakan bahwa Project Based Learning adalah model pembelajaran yang berfokus pada konsep-konsep dan prinsip-prinsip utama dari suatu disiplin, melibatkan peserta didik dalam kegiatan pemecahan masalah dan tugas-tugas bermakna lainnya, memberi peluang peserta didik bekerja secara otonom, mengkonstruk belajar mereka sendiri dan puncaknya menghasilkan karya peserta didik bernilai dan realistik.

\subsection{Sikap terhadap ekosistem sungai}

Peningkatan rerata terkoreksi peserta didik yang difasilitasi pembelajaran berbasis proyek memiliki peningkatan sikap lebih tinggi 6,2\% dari peserta didik yang difasilitasi pembelajaran konvensional. Melalui uji statistik (ANAKOVA), variabel strategi pembelajaran diperoleh nilai $F_{\text {hitung }}$ sebesar 97.95 dengan nilai signifikansi 0,000 (kurang dari 0,05); dengan demikian hipotesis nol ditolak dan hipotesis penelitian diterima yang berarti ada pengaruh strategi pembelajaran terhadap sikap peserta didik terhadap ekosistem sungai. 
PjBL meningkatkan sikap peserta didik terhadap lingkungan hidup karena awalnya $\mathrm{PjBL}$ mampu menanamkan konsep yang benar dan maksimal untuk perkembangan berfikir peserta didik.Melalui pemahaman konsep yang tinggi peserta didik mampu memahami posisi peserta didik dalam lingungan, fungsi atau peran peserta didik di lingkungan, hingga fungsi dan peran komponen biotik dan abiotik (selain peserta didik) dalam lingkungan tersebut.

Konsep ini yang selanjutnya mempengaruhi sikap peserta didik terhadap lingkungan. Peran PjBL sebagai komponen pendidikan yang berdampak pada perubahan sikap peserta didik terhadap ekosistem sungai sesuai dengan pendapat Wahyudi (1986) yang menyatakan bahwa jalur pendidikan merupakan usaha untuk mencapai terwujudnya masyarakat yang memiliki sikap dan perilaku berwawasan lingkungan.Sekolah sebagai lingkungan belajar mempunyai peran strategis terhadap pemberdayaan sikap. Proses belajar melibatkan proses komunikasi dan transfer pengetahuan dan nilai, sehingga sikap peserta didik terbentuk melalui kognisi dalam belajar peserta didik.

Gerungan (2000) mengemukakan bahwa sikap dapat ditumbuh kembangkan melalui proses belajar. Penerapan pembelajran berbasis konstruktivistik dalam hal ini adalah Project Based Learningpada mata pelajaran Biologi merupakan upaya pembinaan kesadaran terhadap manfaat pelestarian ekosistem lingkungan hidup. Melalui pembelajaran konstruktivistik, misalnya Project Based Learning, peserta didik dilatih mengkonstruk sendiri pengetahuan pribadinya sehingga dari kegiatan pembelajaran peserta didik merasa memiliki dan mencintai lingkungannya serta dapat membentuk sikap dan perilaku positif terhadap lingkungan.

PGHP (2008) menyatakan bahwa implementasi metode pembelajaran $\mathrm{PjBL}$ juga mendorong pengembangan produk pembelajaran secara nyata sesuai dengan kegiatan sebenarnya, yang secara alami membuat peserta didik mengalami pembelajaran yang bermakna. Pengembangan produk ini menumbuhkan sikap positif peserta didik tehadap lingkungan sekitarnya.

Sikap positif terhadap lingkungan melalui metode pembelajaran $\mathrm{PjBL}$ juga terbentuk akibat nilai sosial yang ada dalam metode PjBL. Dalam PjBL peserta didik terbiasa berinteraksi dengan rekan sekelompok untuk menyusun berbagai rancangan aktifitas yang berkaitan dengan materi.Peserta didik terbiasa berdiskusi sehingga sumber belajar peserta didik tidak hanya berfokus pada penjelasan guru.Vigotsky (1978) menyatakan bahwa sistem pengajaran kelompok kerja kooperatif, evaluasi peserta didik, pertukaran informasi online adalah aspekaspek kolaboratif dari sebuah proyek. Teori-teori kognitif yang baru dan konstruktivistik menegaskan bahwa belajar adalah fenomena sosial, dan bahwa peserta didikakan belajar lebih di dalam lingkungan kolaboratif. Melalui kerja kolaboratif peserta didik mengamati dan mempelajari sikap dari rekan yang lain yang disadari atau tidak akan mempengaruhi sikap peserta didik, khususnya sikap terhadap ekosistem sungai.

Penelitian yang menunjukkan bahwa PjBL mampu meningkatkan sikap peserta didik terhadap ekosistem sungai antara lain: Atmidha (2009) yang menyatakan bahwa strategi pembelajaran berbasis proyek (PjBL) mempengaruhi sikap peserta didik terhadap ekosistem sungai, Gerungan (2000) yang mengemukakan bahwa sikap peserta didik dapat diberdayakan melalui proses belajar, serta Mahanal, dkk (2009) yang menyatakan bahwa pembelajaran lingkungan hidup berbasis proyek berpengaruh terhadap perkembangan sikap peserta didik.

Metode PjBL berdasarkan penjelasan di atas menunjukkan potensi 
PjBL dalam meningkatkan hasil belajar peserta didik, terutama dalam hal pemahaman konsep dan peningkatan sikap peserta didik terhadap ekosistem sungai. Akan tetapi, pelaksanaan PjBL di kelas X.2 SMA Negeri 9 Malang yang dilakukan oleh praktikan tidak dapat dikatakan sempurna karena terdapat beberapa kekurangan dalam proses belajar mengajar, misalnya: 1) waktu pelaksanaan metode $\mathrm{PjBL}$ sedikit terganggu oleh banyaknya hari libur (libur midle semester, libur persiapan UAN, libur menghadapi lomba antar sekolah) sehingga mengganggu kelancaran proses belajar mengajar. 2) kapasitas peserta didik yang berjumlah 39 terlalu banyak, sehingga praktikan tidak bisa mengamati secara detail perkembangan hasil belajar yang dialami peserta didik. Proses belajar mengajar yang melibatkan peserta didik dalam jumlah yang tinggi berpotensi menciptakan situasi belajar yang lebih ramai dan praktikan harus lebih bijaksana dalam mengendalikan situasi yang kurang kondusif dalam pembelajaran (peserta didik sering bergurau dan kurang fokus). Jumlah peserta didik ideal menurut Permen Diknas No 41 Tahun 2007 yang selanjutnya diatur lebih rinci dalam Pedoman Teknis Penerimaan Peserta Didik Baru Tahun 2009/2010 adalah maksimal 36 peserta didik.

\section{KESIMPULAN}

1. Metode pembelajaran Project Based Learning (PjBL) berpengaruh nyata secara statistik terhadap pemahaman konsep peserta didik. Peserta didik yang difasilitasi pembelajaran berbasis proyek memiliki pemahaman konsep lebih tinggi $47,31 \%$ dari peserta didik yang difasilitasi pembelajaran konvensional.

2. Metode pembelajaran Project Based Learning (PjBL) berpengaruh nyata secara statistik terhadap peningkatan sikap peserta didik terhadap ekosistem sungai. Peserta didik yang difasilitasi pembelajaran berbasis proyek memiliki sikap lebih tinggi 6,2\% dari peserta didik yang difasilitasi pembelajaran konvensional.

\section{DAFTAR PUSTAKA}

Asiska, 2008. Belajar Berbasis Proyek, (Online), (http://www. lubisgrafura.wordpress.com, diakses 24 April 2009)

Buck Institutute for Education. 1999. Project-Based Learning, (Online), (http://www.bgsu.edu/ organizations/etl/proj.html, diakses pada 10 Maret 2009)

Bereiter, C., \& Scardamalia, M. 1999. Process and Product in PBL Research. Toronto: University of Toronto

Corebima, A.D. 2009. Pembelajaran Berbasis Proyek. Makalah disajikan dalam Pelatihan Pengembangan Perangkat Pembelajaran Deteksi Kualitas Air Sungai dengan Indikator Biologi Berbasis Konstruktivistik, Arboretum Sumber Brantas Batu. 28 Februari

Dimyati \& Mudjiono. 1994. Belajar dan Pembelajaran. Jakarta: Proyek Pengembangan dan Peningkatan Mutu Tenaga Kependidikan.

Gaer, S. 1998. What is Project-Based Learning?, (Online), (http://members .aol.com/ CulebraMom/ pblprt.html, diakses tanggal 5 Juni 2009).

Huda, A. 2009.Peningkatan Mutu Pembelajaran dengan Pembelajaran Berbasis Proyek (Online), (http://gatothp2000.wordpress.com/ 2008/02/27/ seaedunet/, diakses tanggal 5 Juni 2009).

Hung, D.W., \& Chen, D.T. 2000.Appropriating and Negotiating Knowledge.educational Technology 
Johnson, D.W., Johnson, R.T. \& Stanne, 2000.Cooperative

Learning

Methods: A Meta-Analysis,

(Online),

(http://www.clcrc.com/pages/clmethods.html, diakses tanggal 2 Juni 2009)

Kamdi, W. 2007. Pembelajaran Berbasis Proyek, (Online), (http://www. lubisgrafura.wordpress.com, diakses 24 April 2009).

Kamdi, W. 2008.Project-Based Learning: Pendekatan Pembelajaran Inovatif .Makalah disampaikan dalam Pelatihan Penyusunan Bahan Ajar Guru SMP dan SMA Kota Tarakan, Tarakan. 31 Oktober s.d. 2 November.

Mahanal, S. 2008.Pengembangan Perangkat Pembelajaran Deteksi Kualitas Sungai dengan Indikator Biologi Berbasis Konstruktivistik untuk Memberdayakan Berpikir Kritis dan Sikap Siswa SMA terhadap Ekosistem Sungai di Malang.Proposal Tesis tidak diterbitkan. Malang: Program Pasca sarjana Universitas Negeri Malang.

Mahanal, S. dan Wibowo, A. L. P. 2009.Penerapan Pembelajaran lingkungan Hidup Berbasis Proyek untuk Memberdayakan Kemampuan Berpikir Kritis, Penguasaan Konsep, dan Sikap Siswa (Studi di SMA Negeri 9 Malang).Makalah disajikan dalam Seminar Nasional Pendidikan Lingkungan Hidup dan Interkonferensi BKPSL.Universitas Negeri Malang.20-21 Juni.

Mappa, S. Dan Basleman, A. 1994. Teori Belajar Orang Dewasa. Jakarta: Direktoral Jendral Pendidikan Tinggi

Moursund, D., Bielefeldt, T., Ricketts, R., \& Underwood, S. 1995. Effect
Practice: Computer Technology in Education. Eugene, OR: ISTE.

Nurhadi; Burhan, Y; Senduk, AG. 2004. Pembelajaran Kontekstual dan Penerapannya dalam KBK. Malang: Universitas Negeri Malang.

Nurohman, S. 2008. Pendekatan $P B L$ sebagai Upaya Internalisasi Scientific Method bagi Mahasiswa Calon Guru (online), (http://www. edutopia.org/modules/PBL/whatpbl. php, diakses tanggal 5 juni 2009).

P'GHP. 2008. Inovasi Project Based Learning (Onlne). (http://gatothp2000 .wordpress.com/2008/02/27/seadune t/., diakses Tanggal 16 Juni 2009).

Purnawan, Y. 2007. Pengenalan Problem Based Learning (Pembelajaran Berbasis Proyek). (Online), (http://www. purnawan.wordpress.com, diakses 24 April 2009)

Purworini, S. E. 2009. Pembelajaran Berbasis Proyek Sebagai Upaya Mengem-bangkan Habit of Mind "Studi Kasus di SMP Nasional KPS Balikpapan" (Online), (www.lubisgrafura.wordpress.com, diakses tanggal 5 Juni 2009).

Rahman, A. 2009. Upaya Peningkatan Motivasi dan Hasil Belajar Biologi Melalui Penerapan Pembelajaran Kooperatif Model NHT (Numbered Heads Together) dalam Inkuiri Terbmbing pada Siswa Kelas $X$ SMA N 6 Malang. Skripsi tidak diterbitkan. Malang: Universitas Negeri Malang.

Richmond, G., \& Striley, J. 1996. Making Meaning in Classrooms: Social Processes in Small-Group Discourse and Scientific Knowledge Building. Journal of Research in Science Teaching, 839-858.

Sasti, S dan Ibnu. 2008. Pembelajaran Berbasis Proyek, (Online), 
(http://www. sf.teadher.org/.. diakses tanggal 5 Juni 2009).

Sudjana, N. 1990. Penilaian Hasil Proses Belajar Mengajar. Bandung: PT. Remaja Rosdakarya.

Sukandriyo, U. 2008. Penerapan Pembelajaran Kontekstual dengan Pendekatan Inkuiri untuk Meningkatkan Sikap dan Hasil Belajar Biologi Siswa Kelas X-4 SMA Negeri 10 Malang. Skripsi tidak diterbitkan. Malang: Universitas Negeri Malang.

Supranata, S. 2004. Analisis Validitas, reliabilitas, dan Interpretasi Hasil Tes. Bandung: Penerbit PT Remaja Rosdakarya

Susanto, P. 1999. Strategi Pembelajaran Biologi di Sekolah Menengah. Malang: Universitas Negeri Malang. Thomas, J.W. 2000.A Review od Research on Project-Based Learning. California: The Autodesk Foundation. Available on: http://www. autodesk.com/foundation

Thoha, M. C. 2003. Teknik Evaluasi Pendidikan. Jakarta: PT. Raja Grafindo Persada.

Tuckman, B. W. 1999. Conducting educational Research. Fifth Editon. New york: Harcourt Brace College Publisher

Vygotsky, L.S. 1978. Mind in Scciety. Cambridge, MA: Harvard University Press.

Wibowo, A. L. P. 2007. Deteksi Kualitas Sungai Brantas dengan Indikator Biologi (di Sungai Brantas, Malang).Skripsi tidak diterbitkan. Malang: Universitas Negeri Malang. Winkell,W.S.1999. Psikologi Pengajaran. Jakarta: Gramedia 